\title{
ASSESSMENT OF BACTERIAL VAGINOSIS INCIDENCE AND NEONATAL OUTCOME ON CASES WITH PRETERM PREMATURE RUPTURE OF MEMBRANES
}

\author{
Demet AYDOGAN KIRMIZI'1, Cuneyt Eftal TANER ${ }^{1}$, Ilkan KAYAR ${ }^{2}$, Asli IRIS ${ }^{1}$, Pelin YAZ ${ }^{3}$, Yildiz OKCU 1 \\ ${ }^{1}$ Ege Maternity and Gynecology Training and Research Hospital, Izmir \\ 2 Osmaniye State Hospital, Osmaniye \\ 3 Sehit Kamil State Hospital, Gaziantep
}

\section{SUMMARY}

Objective: The effect of bacterial vaginosis on cases with preterm premature rupture of membranes (PPROM) was searched via screening for bacterial vaginosis $(B V)$ in cases with PPROM and healthy pregnant women during same gestational weeks.

Material and method: The study incorporated 121 patients who applied to obstetrics poly-clinics at our hospital. Detailed medical histories were obtained from all patients, prior to vaginal examination by sterile speculum. Vaginal samples were taken for analysis via Nugent scoring system. Through verbal scoring, the symptoms due to vaginitis, namely, vaginal discharge, vaginal burning, pruritis, dysuria and malodor were recorded. With regard to pre- and postnatal periods, age, gestational week, complete blood count values, history of gravida, parity and abortion, history of PPROM and duration, gestational week at the time of delivery, mode of delivery of the cases and maternal morbidity were evaluated. All participants were asked to grant informed consents. The study was held under approval by Ethics Committee of the Hospital.

Results: The study incorporated 72 cases of pregnant women with PPROM as study group, and 49 cases of healthy pregnant women as control group. No statistically significant difference was determined in terms of average age, gravida and parity values. Nugent scoring system revealed bacterial vaginosis in 75 cases $(75 / 121 ; 61.9 \%)$ in total: 43 in PPROM study group (43/72; $35.5 \%$ ) and 32 in control groups (32/49; 26.4\%). Statistically, BV was determined at a higher ratio in PPROM study group; similarly, vaginal delivery ratio was higher and APGAR scores of neonates at 1 st and $5^{\text {th }}$ minutes were lower in PPROM study group, compared to control group $(p<0.05)$.

Conclusion: Bacterial vaginosis is a frequently detected infectious disease for pregnant women. It can be considered as an important factor in etiology of PPROM and perinatal morbidity.

Key words: bacterial vaginosis, preterm premature rupture of membranes, nugent score.

Journal of Turkish Society of Obstetrics and Gynecology, (J Turk Soc Obstet Gynecol), 2013; Vol: 10, Issue: 2, Pages: 72- 8

\section{PRETERM ERKEN MEMBRAN RÜPTÜRÜOLGULARINDA BAKTERIYYEL VAGINOZIS INSIIDANSI VE NEONATAL SONUQ̧LARIN DEĞERLENDİRILMESI}

\section{ÖZET}

Amaç: Preterm erken membran rüptürü (PEMR) tanısı konan gebelerde ve benzer gebelik haftalarındaki sağlıklı gebelerde bakteriyel vaginozis (BV) araştırılarak BV'nin PEMR olgularındaki etkisi araştırıldı

Gereç ve yöntemler: Hastanemiz gebe polikliniklerine başvuran toplam 121 hasta çalışmaya alındl. Tüm hastalara ayrıntılı anamnezi takiben steril spekulum ile vajinal muayene yapıld. BV tanisında kullanılan Nugent skorlaması için vaginal örnekleme alındı. Olguların vaginite bağlı olabilecek yakınmalarl; akıntı, yanma, kaşıntı,dizüri,koku semptomları verbal skorlama ile belirlendi. Çalıșmaya alınan olguların yaş, gravida, parite, abortus hikayesi, gebelik haftası, membran rüptür öyküsü ve süresi, hemogram değerleri doğum haftasl, doğum şekli, doğum öncesi ve sonrası

Address for Correspondence: Dr. Demet Aydoğan Kırmızı. Ege Doğum Evi, Kadın Hastalıkları ve Eğitim Hastanesi, İzmir Phone: + 90 (506) 3703287

e-mail: aydogandemet2003@yahoo.com

Received: 09 July 2012, revised: 24 October 2012, accepted: 17 December 2012, online publication: 17 December 2012 
maternal morbidite sonuçları değerlendirildi. Çalışma iç in hasta onamı ve hastane etik kurul onayı alındı Bulgular: Preterm erken membran rüptürü tanısı alan 72 hasta ve kontrol grubu olarak sağllkll 49 gebe çalışmaya alındl. Gruplar arasında yaş, gravida ve parite ortalamaları bakımından istatistiksel olarak anlamlı bir farklılı saptanmadı. Çalıșmaya alınan 121 hastanın 75 'inde (\%61.9) Nugent skoruna göre BV (+) saptand. PEMR grubunda 43 gebede (\%35.5), kontrol grubunda ise 32 gebede (\%26.4) BV saptandi. Ístatistiksel olarak PEMR grubundaki hastalarda kontrol grubuna göre daha yüksek oranda BV saptandı $(p<0.05)$. PEMR grubundaki hastaların normal doğum oranı daha yüksek ve 1.ve 5.dakika Apgar skorları kontrol grubundaki hastalardan anlamlı derecede düşük olarak saptandı ( $<<0.05)$. Sonuç: Bakteriyel vaginozis gebelerde sık görülen vaginal enfeksiyonlardan biri olup, PEMR etyolojisinde ve sonucundaki perinatal morbiditede önemli bir etken olarak kabul edilebilir.

Anahtar kelimeler: bakteriyel vaginozis, erken membran rüptürü, nugent skoru

Türk Jinekoloji ve Obstetrik Derneği Dergisi, (J Turk Soc Obstet Gynecol), 2013; Cilt: 10, Sayl: 2, Sayfa: 72- 8

\section{INTRODUCTION}

$80 \%$ of premature births are caused by spontaneous preterm actions and PPROM. The causes of rest $20 \%$ depends on maternal and fetal causes. PROM is observed in $5-15 \%$ of all childbirths and $20-40 \%$ of preterm childbirths. But PPROM, which is seen in $1-4 \%$ of all pregnancies, takes place within the factors seriously increasing the risks of perinatal mortality, neonatal mortality and maternal infection(1).

The most frequent complication occurring after PROM is intrauterine infection. In 13-60\% of PPROM cases, chorioamniyotis is observed, and decollement placenta is observed in $4-12 \%$ of PPROM cases. Postpartum hemorrhage and placenta retention as a result of infection $(12 \%)$ are seen more frequently in PPROM cases than in other pregnancies ${ }^{(2)}$. The frequency and severity of neonatal complications may change depending on the week of pregnancies when membrane rupture is formed. The studies which were conducted right after membrane rupture showed that the isolation of pathologic microorganisms from vaginal flora may play role in PROM pathogenesis of bacterial infection. Some organisms causing the group B streptococcus, Staphylococcus aureus, Trichomonas vaginalis and bacterial vaginosis may shatter the collagen by secreting protease ${ }^{(3)}$. The inflammatory response of host occurring secondary to bacterial infection plays role in PROM pathogenesis. $\mathrm{BV}$ is the most frequently seen genital infection in pregnant women. The incidence is represented as 2$12 \%$ and $9-28 \%$ in some resources (4).

Within the scope of our study, the BV was researched in pregnant patients applying with PPROM diagnosis and in healthy pregnant women in same gestational weeks. The fetal prognosis is compared within the two groups.

\section{MATERIAL AND METHOD}

72 cases applied to our hospital with premature rupture of membranes symptom and had the definitive diagnosis, and 49 healthy pregnant women, as control group, were incorporated in study. In PPROM group, there were 72 pregnant women between $20^{\text {th }}$ and $37^{\text {th }}$ gestational weeks. For control group, the pregnant women who applied for pregnancy control and had no complaint about water break and whose membrane rupture diagnosis were eliminated by routine anamnesis and examination were included. In that group, there were 49 pregnant women between $20^{\text {th }}$ and $37^{\text {th }}$ gestational weeks. The pregnant women who has not experienced any preterm childbirth, preterm membrane rupture or multiple pregnancies in their previous pregnancies, who has no uterine pathology or anomaly diagnosed formerly, and whose ultrasonographic fetal biometrical measurements were within the normal limits as of the date of last menstrual period, were included in study. The pregnant women who has vaginal hemorrhage and the women who has diagnosed as placenta previa but who has not kept up with followup regularly were excluded from study.

After detailed anamnesis, vaginal examination was applied to all of patients by sterile speculum. During vaginal examination; patients were evaluated in terms of liquid ponding, liquid drainage from cervix during Valsalva maneuver, cervical patency and effacement. Then vaginal samples were taken from patients for Nugent scoring. During Nugent score evaluation, swab samples were evaluated by microbiology specialist in microbiology laboratory of our hospital by applying gram coloration and spreading on lamellae without any information about the patient group of case.

For scoring; the existences big gram $(+)$ bacillaries (lacto- 
bacillary), small gram labile bacillaries (G. vaginalis), small gram (-) bacillaries (Bacteroides spp.) and curly gram labile bacillaries (Mobilincus spp.) were examined. The existence of each or morpho-type was evaluated in accordance with their numbers in each of immersion region. Their values were as follows; $1+$ if there is none of them, $2+$ if there are 1-4 pcs, $3+$ if there are 5-30 pcs and $4+$ if there are more than $30 \mathrm{pcs}$. The scoring was performed between 0 and 10 in accordance with those values.

The complaints of cases, which may depend on vaginitis, such as symptoms of discharge, burning sensation, pruritus and dysuria were determined via verbal scoring. The scores were as follows; 0 if there is no complaint, 1 if there are light complaints (staining in underwear), 2 if there are medium complaints (need for using pads), 3 if there are severe complaints (need for changing pads continuously).

SPSS for windows 10.0 statistical package software was used for evaluations of data. For comparisons; continuity correction test, Pearson chi-square test, Kruskal Wallis test and Mann-Whitney-U Test were used. The values of diagnosis were calculated and $\mathrm{p}<0.05$ was accepted as significant.

\section{FINDINGS}

72 patients with preterm premature rupture of membranes (PPROM) diagnosis and 49 healthy pregnant women, as control group, were included in study. The mean age of PPROM group was $29.01 \pm$ $6.6(18-46)$, and the mean age of control group was $26.49 \pm 5.63$ (17-39). No statistically significant difference was observed between groups in terms of age, gravida and parity means $(\mathrm{p}>0.05)$ (Table I).

Table I: The range of PPROM and control groups in terms of age of mothers, the numbers of pregnancies and parity.

\begin{tabular}{lccc}
\hline & $\begin{array}{c}\text { PPROM group } \\
(\mathbf{n = 7 2})\end{array}$ & $\begin{array}{c}\text { Control group } \\
(\mathbf{n = 4 9 )}\end{array}$ & $\mathbf{p}$ \\
\hline Age & $29.01 \pm 6.6$ & $26.49 \pm 5.63$ & NS \\
Gravide & $2.18 \pm 1.41$ & $2.14 \pm 1.08$ & NS \\
Parity & $1.79 \pm 0.95$ & $1.80 \pm 0.68$ & NS \\
\hline : significant $\mathbf{N S}:$ non-significant & &
\end{tabular}

S: significant, $N S$ : non-significant
In 75 of included 121 patients $(61.9 \%)$, BV $(+)$ was detected according to Nugent score (43 patients in PPROM group (35.5\%) and 32 patients in control group (26.4\%)) (Table II). Statistically, BV was observed in patients in PPROM group more frequent than in patients in control group $(\mathrm{p}<0.05)$.

When the discharge, burning sensation, smell and dysuria symptoms of two groups were compared, the symptoms in PPROM group were observed statistically significantly more frequent (Table III) $(\mathrm{p}<0.05)$.

Table III: The range of vaginitis-caused symptoms in PPROM and control group patients.

\begin{tabular}{llllll}
\hline & \multicolumn{2}{l}{ PPROM } & \multicolumn{2}{c}{ Control Group } & p \\
& n & \% & n & \% & \\
\hline Discharge & 61 & $\% 58,6$ & 43 & $\% 41,4$ & $\mathrm{~S}$ \\
\hline Pruritus & 52 & $\% 83,8$ & 10 & $\% 16,1$ & $\mathrm{~S}$ \\
Burning sens. & 50 & $\% 92,5$ & 4 & $\% 7,5$ & $\mathrm{~S}$ \\
Smell & 61 & $\% 71,7$ & 24 & $\% 28,3$ & $\mathrm{~S}$ \\
Dysuria & 52 & $\% 85,2$ & 9 & $\% 14$ & $\mathrm{~S}$ \\
& & & & & \\
\hline S. significant & & & & &
\end{tabular}

PPROM and control group patients were expressed in Table IV in terms of type of childbirth. In patients with PPROM, the rate of normal vaginal delivery was determined statistically significantly higher than in control group, $(\mathrm{p}<0.05)$.

Table IV: The type of childbirth in PPROM and control group patients.

\begin{tabular}{lcccc}
\hline & \multicolumn{2}{c}{ G sarean section } & \multicolumn{2}{c}{ Normal birth } \\
Group & $\mathbf{n}$ & $\mathbf{\%}$ & $\mathbf{n}$ & $\mathbf{\%}$ \\
\hline PPROM group & 29 & $\% 24,0$ & 43 & $\% 35,5$ \\
Control group & 25 & $\% 20,7$ & 24 & $\% 19,8$ \\
\hline
\end{tabular}

In PPROM cases; the duration from occurring of membrane rupture to start of delivery was accepted as latent period. In order to compare statistical analyses of cases, they were separated into 3 classes as 24 hours and less, 24 - 48 hours and more than 48 hours. The mean latent period was determined as $3.8 \pm 4.7$ day (Table V).

Table II: The Nugent Score range of PPROM and control groups patients.

\begin{tabular}{lccccccc}
\hline Nugent Score & 3 & 4 & 5 & 6 & 7 & 9 \\
PPRom group $(\mathrm{n})$ & 12 & 12 (clu cell+) & 5 (clu cell+) & 16 (clu cell+) & 18 & - \\
Control group $(\mathrm{n})$ & 1 & 8 (clue cell+) & 8 (clu cell+) & 4 (clue cell+) & 19 & 5 \\
\hline
\end{tabular}


Table V: The range of latent period in PPROM cases according to gestational week

\begin{tabular}{lcccccc}
\hline & \multicolumn{2}{c}{$\leq \mathbf{2 4}$ hours } & \multicolumn{2}{c}{$\mathbf{2 4 - 4 8}$ hours } & \multicolumn{2}{c}{$\geq \mathbf{4 8}$ hours } \\
& $\mathbf{n}$ & $\mathbf{\%}$ & $\mathbf{n}$ & $\mathbf{\%}$ & $\mathbf{n}$ & $\mathbf{\%}$ \\
\hline$\leq 28 \mathrm{w}$ & 2 & $\% 10.5$ & 2 & $\% 10.5$ & 15 & $\% 78.9$ \\
$29-32 \mathrm{w}$ & 6 & $\% 30$ & 8 & $\% 40$ & 6 & $\% 305$ \\
$\geq 33 \mathrm{w}$ & 23 & $\% 69.6$ & 7 & $\% 21.2$ & 3 & $\% 9$ \\
Total & 31 & $\% 43.0$ & 17 & $\% 23.6$ & 24 & $\% 33.3$ \\
\hline
\end{tabular}

The rate of caserrian section due to fetal distress in PPROM group was higher than that of in control group $(\mathrm{p}=0.00)$. According to all caserrian section indications, no difference was observed between groups in terms of repeating caserrian section indication rates $(\mathrm{p}>0.05)$. When the range of delivery type is evaluated according to gestational week, it was observed that the difference between groups was not statistically significant (Table VI) $(\mathrm{p}>0.05)$.

Table VI: The range of PPROM cases according to type of childbirth and gestational week.

\begin{tabular}{lcccccc}
\hline Group & $\begin{array}{c}\text { Spontaneous } \\
\text { normal } \\
\text { birth }\end{array}$ & \multicolumn{2}{c}{$\begin{array}{c}\text { Induction } \\
\text { normal } \\
\text { birth(n) }\end{array}$} & G-sarean(n) \\
& n & $\%$ & n & $\%$ & n & $\%$ \\
\hline$\leq 28 \mathrm{w}$ & 9 & $\% 42.1$ & 2 & $\% 10.5$ & 8 & $\% 42.1$ \\
$29-32 \mathrm{w}$ & 3 & $\% 15$ & 6 & $\% 30$ & 11 & $\% 55$ \\
$\geq 33 \mathrm{w}$ & 8 & $\% 24.2$ & 15 & $\% 45.4$ & 10 & $\% 30.3$ \\
Total & 920 & $\% 27.7$ & 23 & $\% 31.9$ & 29 & $\% 40.2$ \\
\hline
\end{tabular}

The PPROM and control group patients are showed in Table VII according to birth weight and gestational week. The birth weight and gestational week of patients in PPROM group were found significantly less than those of patients in control group.

Table VII: The birth weight and birth week values of patients in PPROM and control groups.

\begin{tabular}{lcc}
\hline & $\begin{array}{c}\text { Weigh of } \\
\text { Birth(g) }\end{array}$ & $\begin{array}{c}\text { Week of } \\
\text { birth(w) }\end{array}$ \\
\hline PPROM group & $1837,78 \pm 672,79$ & $31.05 \pm 24.05$ \\
Control group & $3336,33 \pm 465,49$ & $38.26 \pm 6.82$ \\
\hline
\end{tabular}

The APGAR scores of patients in PPROM group at 1 st and $5^{\text {th }}$ minutes $(5.9-7.19)$ were determined significantly less than those of patients in control group $(7.61-8.55)(\mathrm{p}<0.05)$.

\section{DISCUSSION}

PROM is seen in 5-10\% of all pregnancies (11.12), and $30-50 \%$ of preterm births ${ }^{(10)}$. Because it is one of the most important causes of maternal and fetal morbidity and mortality, the rapid and accurate diagnosis of PROM is important.

The studies in recent years support the role of infection in etiology of preterm actions. The roles of sub-clinic infection of placental membrane, chorioamniotitis forming after and before chorioamnion membranes, and histological infection in etiology gain importance (5-7). Microorganisms were isolated 2-4 folds more frequent in placental membranes of pregnant women who had preterm childbirths than pregnant women who had childbirths in term ${ }^{(5)}$.

While bacterial vaginosis is one of the most frequent infections seen in pregnant women, $50 \%$ of women are asymptomatic. The causing of infection to "abortus, preterm childbirth, prematurity, premature rupture of membranes, amniotic fluid infection and postpartum sepsis" increases its clinical importance ${ }^{(8-11)}$. It was determined that premature rupture of membranes is seen in pregnant women with BV 7.3 times more(12). In caserrian section cases with bacterial vaginosis, it was determined that postpartum endometritis and wound infection development rates are 5 times more than patients without $\mathrm{BV}^{(12-14,16,17)}$.

When the studies were viewed in order to research the vaginal infections in pregnant women, Di Bartolomeo et al. ${ }^{(18)}$ found BV in $27.5 \%$ of 198 pregnant women, Candida forms in $34.3 \%$, Group B streptococcus in $4.5 \%$ and Trichomonas Vaginalis in 3.5\%. Within 284 pregnant women, Begüm et al. ${ }^{(19)}$. found $\mathrm{BV}$ in $17.7 \%$ and Trichomonas Vaginalis in $1.4 \%$, and they expressed that BV rate was higher in women with lower socioeconomical conditions.

Within 534 pregnant women, Gravett et al. detected bacterial vaginosis in $19 \%$ of them (102 women), and it was showed that $24 \%$ of patients with BV had preterm childbirth $^{(20)}$. Within 5432 pregnant women between $10^{\text {th }}$ and $17^{\text {th }}$ gestational weeks, Keki et al. determined the BV prevalence as $10.4 \%$.

In a Cochrane meta-analysis study, during evaluation of 15 studies covering 5888 pregnant women with asymptomatic BV and average preterm childbirth risk; the elimination of infection by antibiotic treatment was seriously efficient. But the rates of preterm childbirths 
and the risk of premature rupture of membrane did not decrease significantly(21).

In another meta-analysis covering 5 studies with total 2387 women, it was determined that preterm childbirth risk can be decreased by treating $\mathrm{BV}$ before $20^{\text {th }}$ gestational week.

Within a meta-analysis study covering 3 studies of United States Preventive Services Task Force (USPSTF) group, no statistically significant decrease was observed in preterm childbirth rates of 526 pregnant women with asymptomatic BV and having low preterm childbirth risk as a result of treatment. In another meta-analysis study of same group covering 8 studies, no significant decrease can be obtained via treatment in preterm birth rates of 4972 pregnant women with medium risk factors and asymptomatic $\mathrm{BV}^{(22)}$. According to those data; preterm birth and its results cannot be prevented via BV scanning and treatment of pregnant women with asymptomatic BV. So the regular treatment of women is not recommended.

During our study, the duration from development of membrane rupture in PPROM cases to beginning of birth was accepted as latent period. Average latent period was $3.8 \pm 4.7$ days, average birth week was $31.05 \pm 24.05$, and average weight of newborn babies was $1837.78 \pm 672.79 \mathrm{~g}$.

Independently from obstetric intervention or clinic table, the most possible result is childbirth in 1 week in PPROM cases without treatment. When gestational week gets earlier, latent period increases parallelly ${ }^{(23)}$. While latent period is less than 48 hours in term pregnancy, it may vary between 1 day and a couple of weeks in preterm cases. $70 \%$ of pregnant women in $29^{\text {th }}-32$ nd weeks after PPROM and $80 \%$ of those in $33 \mathrm{rd}-36^{\text {th }}$ weeks give birth in 2 days, it was reported that although it varies due to gestational week, mean latent period is 8.8 days ${ }^{(2)}$. In the study of Mercer et al. (24), it was stated that latent period is longer in early weeks of pregnancy, and induction response is lower than expected because cervical maturation is not completed. We calculated the mean latent period as $3.8 \pm 4.7$ days and we determine that it lasts longer in earlier weeks of pregnancy. While latent period is longer than 24 hours in $89.4 \%$ of pregnancy cases in $28^{\text {th }}$ and less weeks, the same duration was observed in $70 \%$ of pregnancy cases in $29^{\text {th }}-32$ nd weeks and $30.2 \%$ of pregnancy cases in $33 \mathrm{rd}$ and more weeks. From different viewpoint, $66.5 \%$ of our PPROM cases experienced labor in first 48 hours. While longer latent period provides time for interventions which can provide lung maturation of fetus, it increases the maternal infection and neonatal sepsis rates significantly.

High caserrian section rate is observed secondary to cord pressure in membrane rupture especially due to oligo-hydramnios and acute fetal distress $(25,26)$. During our study, the rate of caserrian section was calculated as $40.2 \%$. While that rate is similar with studies of Tanır (34\%) (27), Pasquier $(43.7 \%)^{(28)}$ and Karabulut $(42.6 \%)^{(29)}$, it was higher than the rates of Kenyon $(29 \%)^{(31)}$ and Ozumba $(14.5 \%)^{(30)}$. The caserrian section rate of control group of our study was calculated as $51.02 \%$. The normal vaginal birth rate in PROM group was higher than control group. We think that this rate was caused by choosing the inductionapplication group from cases with higher vaginal childbirth possibility (higher pregnancy age, appropriate Bishop score, enough amnion fluid).

The caserrian section rate was determined as $17.8 \%$ in cases where induction was applied. This result developed due to fetal distress arising as a result of induction. In cases with membrane rupture, secondary to decrease in the amount of amnion fluid, the risks of fetal distress, ablatio placenta and cord prolapsus increase $^{(25)}$. For PPROM cases, it was reported that the risk of cord prolapsus is $1-2 \%$, the incidences of ablatio placenta and acute fetal distress vary between 2 and $10 \%$ and 2 and 20\% respectively( ${ }^{(29)}$. During our study, we calculated those incidences as $1.85 \%, 1.85 \%$ and $31.4 \%$. Those values significantly differ from rates in literature. When considering APGAR score, 1st minute score in PROM group was 5.90 \pm 2.08 and $1 \mathrm{st}$ minute score in control group was $7.61 \pm 0.73 .5^{\text {th }}$ minute APGAR score was determined as $7.61 \pm 0.73$ in PROM group and as $8.55 \pm 0.65$ in control group. The perinatal morbidity and mortality in cases with PPROM vary according to gestational week. As expected, the 1th and $5^{\text {th }}$ minutes APGAR scores of newborns were found lower in earlier gestational weeks. Besides problems which are caused by prematurity, the higher infection risk which is seen especially in cases where latent period lasts longer is seen as responsible from that decrease. This result is in accordance with other studies which were conducted in this field(29). In their study, Tanır et al. ${ }^{(27)}$ compared 80 preterm childbirths with PPROM and 100 preterm childbirths without 
PPROM, and they did not find any difference between two groups in terms of 1 st and $5^{\text {th }}$ minutes newborn APGAR scores.

Result: Bacterial vaginosis is one of the most frequent vaginal infections seen in pregnant women. It can be accepted as an important factor in PPROM etiology and perinatal morbidity which is a result of PPROM etiology.

\section{REFERENCES}

1. Gelişen O, Çalışkan E. Erken membran rüptürü. Beksaç MS, Demir N, Koç A, Yüksel A (Editörler). Obstetrik, MaternalFetal Tip ve Perinatoloji. Ankara: Nobel Tıp Kitabevi; 2001. s.1156- 65 .

2. Mercer BM, Goldenberg RL, Moaward AH, Shellhaas C, Das A, Menard M.K, et al. The preterm prediction study: prediction of preterm premature rupture of membranes through clinical findings and ancillary testing. Am J Obstet Gynecol 2000; 183: $738-45$

3. Ferguson SE, Smith GN, Salenieks ME, Windrim R, Walker MC. Premature rupture of the fetal membranes: Nutrutional and Socioeconomic Factors. Obstet Gynecol 2002; 100: 12506.

4. Sharon L.Hiller, Ph.D., Robert P. Nugent, Ph.D., David A. Eshenbach, M.D, Marijane A. Krohn, Ph. D, Ronald S. Gibbs, M.D., David H. Martin, M.D., Mary Frances Cotch, Ph.D., Robert Edelman, M.D., Joseph G. Pastorek II, M.D., A. Vijaya Rao Ph.M.D., Donald Mc Nellis, M.D., Joan A. Regan, M.D., J. Christopher Carey, M.D., ve Mark A. K. Lebanoff, M.D., For the vaginal infection and study Group, Association between bacterial vagnosis and preterm delivery of a lowbirth-weight infant, the New England Journal Of Medicine 1995; vol 333 no: $26: 1737-42$.

5. Kişnişçi, Gökşin: Durukan: üstay, Ayhan, Gürgan, Önderoğlu. Temel Kadın Hastalıkları ve Doğum bilgisi. 1996; 1465- 80.

6. Creasy RK, Merkatz IR: Preventation of preterm birth: Clinical opinion obstet gynecol 76: 2S- 4S, 1990.

7. Cunningham, Gant, Leveno, Gilstrap; Williams Doğum Bilgisi 2001: 21. Bask1 Cilt 1 s689- 727.

8. Chen KCS, Forsth PS, Buchanan TM, Holmes KK. Amine content of vaginal fluid from untreated and treated patients with nonspecific vaginitis. J Clin Invest 1979; 63: 828- 35.

9. Marai W. Lower genital tract infections among pregnant women: a review. East Afr Med J 2001; 78: 581- 5.

10. Martius J, Eschenbach DA. The role of bacterial vaginosis as a cause of amniotic fluid infection, chorioamnionitis and prematurity: A review.Arch Gynecol Obstet 1990; 274: 1- 13.

11. Donders GGG, Vereecken A, Eugene B, Dekeersmaecker A, Salembier G, Spitz B. Definition of atype of abnormal vaginal flora that is distinct from bacterial vaginosis: aerobic vaginitis. BJOG 2002; 109: 34- 43.

12. McGregor JA, Lawellin D, Franco-Buff A, Todd JK, Makowski EL. Protease production by microorganisms associated with reproductive tract infection. Am J Obstet Gynecol 1986; 154 : 109- 14.

13. McGregor JA, French JI. Bacterial vaginosis in pregnancy. Obstet Gynecol Surv 2000; 55 (Suppl 1): 1- 19.

14. Morales WJ, Schorr S, Albritton J. Effect of metranidazole in patients with term birth in preceding pregnancy and bacterial vaginosis: a placebocontrolled, double- blind study. Am J Obstet Gynecol 1994; 171: 345- 7.

15. Carr PL, Felsenstein D, Friedman RH. Evaluation and management of vaginitis. J Gen Intern Med 1998; 13: 33546.

16. Krohn MA, Hillier SL, Eschenbach DA. Comparsion of methods for diagnosing bacterial vaginosis among pregnant women. J Clin Microbiol 1992; 27: 1266- 71.

17. Gomez R, Ghezzi F, Romero R, Munoz H, Tolosa JE, Rojas I. Premature labour and intra-amniotic infection. Clinical aspects and and role of the cytokines in diagnosis and pathophysiology. Clin Perinatol 1995; 22: 281

18. Di Bartolomeo S, Rodriguez M, Sauka D, Alberto De Torres R. Microbiologic profile in symptomatic pregnant women's genital secretions in Gran Buenos Aires, Argentina. Enferm Infecc Microbiol Clin 2001; 19: 99- 102

19. Begum A, Nilufar S, Akther K, Rahman A, Khatun F, Rahman M. Prevalence of selected reproductive tract infections among pregnant women attending an urban maternal and childcare unit in Dhaka, Bangladesh. J Health Popul Nutr 2003; 21: 112- 6 .

20. Gravett MG, Nelson HP, De Rowen T, et al. Independent assosiciations of bacterial vaginosis and chlamidia trachomatis infection with adverse pregnancy outcome. Journal of American Medical Association. 1986; 256: 1899- 903.

21. McDonald HM,Brocklehurst P, Gordon A. Antibiotics for treating bacterial vaginozis in pregnancy. Cochrane Database Syst Rev 2007; CD000262

22. Nygren P, Fu R, Freeman M, et al. Evidence on the benefits and harms of screening and treating pregnant woman who are asymptomatic for bacterial vaginosis: an update review for the U.S. Preventive Services Task Force. Ann Intern Med 2008; 148: 220 .

23. ACOG Committee on Practice Bulletins-Obstetrics. ACOG Practice Bulletin No. 80:premature rupture of membranes. 
Clinical management guidelines for obstetrician-gynecologists. Obstet. Gynecol 2007; 109(4): 1007- 19.

24. Mercer BM. Managment of premature rupture of membranes before 26 weeks'gestation. Obstet Gynecol Clin North Am 1992; 19: 339- 351.

25. Vintzileus AM. Tests of fetal well-being in premature rupture of RFmembranes; rationals and results. Clin North Am Obstet Gynecol 1992; 19(2): 281- 309.

26. Lewis DF, Adair CD, Robichaux AG et al. Antibiyotic thrapy in preterm premature rupture of membranes: are seven days necessary? A preliminary, randomized clinical trial. Am J Obset Gynecol 2003; 188: 1413- 6.

27. Tanir HM, Sener T, Tekin N, Aksit A, Ardic N. Preterm premature rupture of membranes and neonatal outcome prior to 34 weeks of gestation. Int J Gynaecol Obstet. 2003; 82(2):
$167-72$.

28. Pasquier JC, Rabilloud M. A prospective population-based study of 598 cases of PPROM between 24 and 34 weeks' gestation: description, management, and mortality. Eur J Obstet Gynecol Reprod Biol. 2005; 121(2):164- 170.

29. Karabulut AA, Durukan T. Prematür membran rüptürü: maternal ve neonatal etkilerin incelenmesi. Perinatoloji dergisi 1999; 7(3): 248- 54.

30. Osmanagaoglu MA, Unal S, Bozkaya H. Chorioamnionitis risk and neonatal outcome in preterm premature rupture of membranes. Arch Gynecol Obstet. 2005; 271(1): 33- 9.

31. Kenyon SL, Taylor DJ, Tarnow-Mordi W. Broad Spectrum Antibiyotics for Preterm Rupture of Membrances. Cochrane Database of Systematic Reviews 2003, Issue2. Art No: CD001058. DOI:10.1002/ 14651858.CD001058. 